\title{
Contribution of Emotional Intelligence towards Graduate Students' Critical Thinking Disposition
}

\author{
Fong-Luan Kang \\ Faculty of Educational Studies, Universiti Putra Malaysia, 43400 UPM, Serdang, Selangor, Malaysia \\ E-mail: kangfongluan@gmail.com
}

Received: 23-08- 2015

Accepted: 24-09-2015

Published: $31-10-2015$

doi:10.7575/aiac.ijels.v.3n.4p.6

URL: http://dx.doi.org/10.7575/aiac.ijels.v.3n.4p.6

\begin{abstract}
Good critical thinkers possess a core set of cognitive thinking skills, and a disposition towards critical thinking. They are able to think critically to solve complex, real-world problems effectively. Although personal emotion is important in critical thinking, it is often a neglected issue. The emotional intelligence in this study concerns our sensitivity to and artful handling of our own and others' emotions. Engaging students emotionally is the key to strengthening their dispositions toward critical thinking. Hence, a study involving 338 male and female graduate students from a public university was carried out. They rated the Emotional Intelligence Scale and Critical Thinking Disposition Scale. Findings suggested that emotional intelligence and critical thinking disposition were positively correlated ( $\mathrm{r}=.609)$. Differences in terms of age, gender, and course of study also formed part of the analysis.
\end{abstract}

Keywords: emotional intelligence, critical thinking disposition, graduate students

\section{Introduction}

To be competitive, the Malaysian government has envisioned that it is crucial for students to be equipped with knowledge, thinking skills, leadership skills, bilingual proficiency, ethics and spirituality and national identity. Hence, they must master a variety of cognitive skills such as critical thinking, creative and innovative problem-solving, and reasoning and learning ability (Ministry of Education Malaysia [MOE], 2013). Critical thinking, according to Ennis (1987), is "reasonable and reflective thinking focused on deciding what to believe or do" and he details numerous proficiencies, tendencies, and dispositions that contribute to such reflective thinking. Critical thinking has been also referred to as the process of "thinking about thinking" as defined and originally purposed by Flavell (1979). Additionally, Halpern (2003) described critical thinking as '...thinking that is purposeful, reasoned, and goal directed the kind of thinking involved in solving problems, formulating inferences, calculating likelihoods, and making decisions...' (p.37). Most frequently cited, however, is the consensus statement on critical thinking composed of a cognitive skills dimensions and an affective dispositions dimension from The Delphi Report by American Philosophical Association (APA). It states: "We understand critical thinking to be purposeful, self-regulatory judgment which results in interpretation, analysis, evaluation, and inference, as well as explanation of evidential, conceptual, methodological, criteriological, or contextual considerations upon which the judgment is based. Critical thinking is essential as a tool of inquiry. As such, critical thinking is a liberating force in education and a powerful resource in one's personal and civic life." (Facione, 1990, p.3) Accordingly, seven constructs have been identified in the California Critical Thinking Disposition Inventory (CCTDI), and they consist of: truth-seeking, open-mindedness, analyticity, systematicity, inquisitiveness, critical thinking self-confidence, and maturity of judgment (Facione, 1992).

Yet many teachers continually struggle to engage students in critical thinking activities (Tempelaar, 2006), and students seldom use critical thinking skills to solve complex, real-world problems (Rippen, Booth, Bowie, \& Jordan, 2002). On the same token, companies overwhelmingly agree that the content and quality of education in local universities do not adequately prepare students for the workforce with respect to critical thinking (Tan, 2014). On one hand, part of the problem lies in the difficulty of fostering transfer across situations and the need to practice skills until they become more automatic patterns of action. Yet, on the other hand, Ritchhart (1997) added that emotion might be the other culprit at work in producing this shortfall of good thinking. He proposed that emotions have projective power over our thoughts and hence are laying the foundation for the thinking that is to come. Emotions act as filters to form our desires, furnish our capacities, and to a large extent rule our immediate thoughts. Brookfield (1987) also agreed that personal emotion is important in - or "central" to critical thinking, but it is a "neglected issue" (Blom Kemdal \& Montgomery, 1997) because the literature is scant and complex.

All human activity is influenced by and influences emotion (Damasio, 2000). To handle emotion well, we need emotional intelligence which concerns our sensitivity to and artful handling of our own and others' emotions (Goleman, 1995). In many ways, emotional intelligence may be considered as among the most promising of the "new constructs" emerging in psychological science that are directed towards improving social adaptation (Matthews, Zeidner, \& 
Roberts, 2002). Recently, social psychologists have heralded emotional intelligence as a major factor determining adaptive interpersonal relationships (Fitness, 2001, 2006). Coincidentally, Brookfield (1987) talks of an important element of critical thinking being the ability to listen and respond to another. In essence, critical thinking is often a direct social activity, and emotional awareness is required in order to properly communicate in a clear and precise manner. On top of this, he says "challenging unquestioned assumptions, looking skeptically at givens we have lived by, and trying to shake off habitual ideas and behaviors so that we can try out alternatives, are emotionally potent activities." In the same context, Nelson-Jones (1994) talks about the process of critical self-appraisal, about the emotional influence of one's own feelings, the letting go of defensiveness, the perceptions of oneself and others more positively and realistically. Moreover, Elder (1996) maintained critical thinking is the key to emotional intelligence. She argued that "critical thinking is the only plausible vehicle by which we could bring intelligence to bear upon our emotional life (p.5)."

Therefore, in order to produce a balanced education with students of high aspirations, the focus should not be too narrowly set on the development of thinking skills alone. Attention must also be paid to developing the dispositions, attitudes, and habits that constitute the intellectual character of students. Likewise, emotions should not be ignored. Given that not many studies focus on the relationship between emotional intelligence and critical thinking, this study was carried out to fill the void. For this study in the context of graduate students, critical thinking disposition instead of critical thinking skill has been chosen because it is a more reliable indicator of how likely a person is to think critically (Bensley, 2006). Additionally, critical thinking disposition is claimed to be "discipline neutral and comprises a generalizable description of the ideal critical thinker across multiple contexts and situations" (Facione, Facione, \& Giancarlo, 2001, p.2).

\subsection{Objectives}

The objectives of this study were to assess the graduate students' level of emotional intelligence and critical thinking disposition followed by the exploration of their possible relationship. Influence of age, gender and course of study on these variables was also studied. Accordingly, three research questions and six hypotheses were formulated to guide the subsequent data analysis.

\subsection{Research questions}

1. What is the level of graduate students' emotional intelligence?

2. What is the level of graduate students' critical thinking disposition?

3. What is the relationship between graduate students' emotional intelligence and critical thinking disposition?

\subsection{Null Hypotheses}

Ho1: Age makes no significant contribution to changes in graduate students' emotional intelligence.

Ho2: Age makes no significant contribution to changes in graduate students' critical thinking disposition.

Ho3: Gender makes no significant contribution to changes in graduate students' emotional intelligence.

Ho4: Gender makes no significant contribution to changes in graduate students' critical thinking disposition.

Ho5: Course of study makes no significant contribution to changes in graduate students' emotional intelligence.

Ho6: Course of study makes no significant contribution to changes in graduate students' critical thinking disposition.

\section{Methodology}

The survey method was followed to collect and analyze the data quantitatively. The study had a cross-sectional design. The data were collected using questionnaires and analyzed through descriptive and inferential statistical methods.

\subsection{Respondents}

The accessible population for this study was all graduate students who were taking compulsory or elective courses in the Faculty of Educational Studies. The cluster random sampling approach was used. Questionnaires were administered to the selected sample of 338 graduate students during class time. All responses were collected immediately upon completion of the questionnaires. Prior to the commencement of data collection, verbal consent was obtained and participation was voluntary. No perceived harm, risk, or possible hurt was anticipated from this study. They were informed to respond honestly and with an open mind. The researcher was present to answer any questions that might arise. The researcher's presence would improve the response rate to close to $100 \%$. Given that the respondents were graduate students who had taken courses in different disciplines prior to enrolling in postgraduate programs of Universiti Putra Malaysia (UPM), caution had to be exercised to ensure that they brought along some variability in responses which might represent their past exposure in emotional intelligence and/or critical thinking disposition.

\subsection{Instruments}

Emotional Intelligence Scale (EIS) was used to measure emotional intelligence. It is a homogeneous construct proposed in Schutte, Malouff, Hall, Haggerty, Cooper, Golden, and Dornheim (1998). The authors permit free use of the 33-item scale for research and clinical purposes and the scale is available in the public domain. It has a five-point rating scale from 1, strongly disagree to 5 , strongly agree. Scores on the EIS were calculated by adding up all scores for items 1 
through 33 of the scale. Items 5,28 , and 33 were scored by reverse coding. Scores ranged from a minimum of 33 to a maximum of 165, with higher scores indicating distinctiveness of emotional intelligence (Edith \& Manoj, 2012).

EIS has shown evidence of good reliability and was common in studies on emotional intelligence. The EIS has been deemed both a valid and reliable scale; Brackett and Mayer (2003) as well as Gardner and Qualter (2010) reported very high coefficients $(\alpha=.93$ and .90 , respectively) for its internal reliability. In this study, the Cronbach alpha coefficient was .839 , way above the ideal .7 suggested by DeVellis (2003). Therefore, the EIS was considered as a reliable scale to be used for this study.

On the other hand, Critical Thinking Disposition Scale (CTDS), a hypothesized two-factor model offered by Sosu (2013) was used to measure critical thinking disposition. Permission to use this instrument, composed of 11 items, was obtained from its developer, who suggested that his model was more parsimonious than the existing models and incorporated the key dispositional elements inherent in existing taxonomies.

CTDS has two constructs, namely, Reflective Scepticism and Critical Openness, with a five-point Likert-type responses ( $1=$ strongly disagree, $5=$ strongly agree). The Reflective Scepticism subscale conveys the tendency to learn from ones past experiences and be questioning of evidence. The Critical Openness subscale meanwhile reflects the tendency to be actively open to new ideas, critical in evaluating these ideas and modifying ones thinking in light of convincing evidence. Some degree of both Reflective Scepticism and Critical Openness are required for an individual to have a disposition to critical thinking. Likewise, higher scores would suggest greater disposition towards critical thinking (Sosu, 2013).

CTDS has good internal consistency, with a Cronbach alpha coefficient of .79 in a sample made up of first year undergraduate students in education and graduate students enrolled on a one-year education programme (Sosu, 2013). Likewise, this study has produced a Cronbach alpha coefficient of .814 suggesting that CTDS is internally consistent and reliable with the sample.

\section{Research Findings}

The data collected through the questionnaires were coded and analyzed by IBM SPSS (Version 21). Exploratory data analysis was conducted to check for errors. The results are presented in this section.

\subsection{Emotional Intelligence}

The respondents' average score for emotional intelligence in this study was 128.25 with a standard deviation of 9.73. Therefore, against a full emotional intelligence score of 165 , the graduate students in this study were considered reasonably emotionally intelligent. As suggested by Schutte, Malouff, Simunek, McKenley, and Hollander (2002) higher scores indicated greater emotional intelligence. The setback was, however, due to the lack of an accurate scoring system and procedure in EIS by Schutte et al. (1998), absolute and objective scoring of the emotional intelligence of graduate students in this study was made impossible.

\subsection{Critical Thinking Disposition}

According to Sosu (2013), the scores of the 11 items can be summed up to provide an overall dispositional score for an individual with a range of 11-55. Scores between 11 and 34 will indicate low disposition; 35-44 moderate disposition; and 45-55 high disposition. A useful strategy should also include examination of subscale scores. Reflective Scepticism will have a range of 4-20 with cut-off ranges being 4-12 low; 13-16 moderate; and 17-20 high. The total score for the Critical Openness subscale will range from 7 to 35 with the following cut-offs (7-21 low; 22-28 moderate; 29-35 high). Therefore, the graduate students in this study have demonstrated high overall critical thinking disposition, but moderate in Reflective Scepticism and Critical Openness. Both the central tendency and variability were summarized in Table 1.

Table 1. Central Tendency and Variability of Critical Thinking Disposition

\begin{tabular}{lcc}
\hline & Mean & Standard Deviation \\
\hline Overall critical thinking disposition & 45.40 & 3.93 \\
Reflective Scepticism & 16.64 & 1.73 \\
Critical Openness & 28.77 & 2.63 \\
\hline
\end{tabular}

\subsection{Emotional Intelligence and Critical Thinking Disposition}

The relationship between emotional intelligence and critical thinking disposition was investigated using Pearson product-moment correlation coefficient. Preliminary analyses were performed to ensure no violation of the assumptions of normality, linearity, homoscedasticity (Pallant, 2010). In this case (Table 2), the Pearson correlation coefficient (.609) was positive, indicating a significant positive correlation between critical thinking disposition and emotional intelligence. It was also found that there was a significant positive relationship between emotional intelligence and the two constructs of critical thinking disposition: Reflective Scepticism $(\mathrm{r}=.547, \mathrm{p}<.05)$ and Critical Openness $(\mathrm{r}=.557$, 
$\mathrm{p}<.05)$. According to Cohen $(1988, \mathrm{pp} .79-81), \mathrm{r}=.50$ to 1.0 indicates a large correlation between the two variables, suggesting quite a strong relationship. This study therefore exhibited significantly quite a strong positive relationship between emotional intelligence and critical thinking disposition.

Table 2. Pearson Correlation Coefficients between Emotional Intelligence and Critical Thinking Disposition

\begin{tabular}{llcl}
\hline Variable & Total emotional intelligence & \\
\hline & $\mathrm{N}$ & Correlation coefficient & Sig. \\
Overall critical thinking disposition & 319 & .609 & .001 \\
Reflective Scepticism & 325 & .547 & .001 \\
Critical Openness & 319 & .557 & .001 \\
\hline
\end{tabular}

\subsection{Emotional Intelligence and Age}

The researcher conducted a one-way between-groups analysis of variance to investigate the difference in age on levels of emotional intelligence, as measured by the EIS. To facilitate this analysis, the age of respondents, a continuous variable in this study, has been collapsed into groups. Consequently, the respondents were divided into five categories according to their age. They were $\leqslant 25,26-28,29-32,33-37$ and $38+$ years old. This study revealed that there was no significant difference at .05 level of significance in EIS scores for the five groups: $F(4,318)=1.754$, $p=.138$ (Table 3 ). Hence, the emotional intelligence of graduate students from different age categories was not significantly different.

iTable 3. One-way variance analysis of differential between the Emotional Intelligence in different age category Table 3. One-way variance analysis of differential between the Emotional Intelligence in different age category

\begin{tabular}{lccccc}
\hline Source & SS & df & MS & F & Sig \\
\hline Between-group & 657.13 & 4 & 164.28 & 1.754 & .138 \\
Within-group & 29784.74 & 318 & 93.66 & & \\
Total & 30441.87 & 322 & & & \\
\hline
\end{tabular}

\subsection{Critical Thinking Disposition and Age}

Likewise, the respondents were divided into five categories according to their age. They were $\leqslant 25,26-28,29-32,33-$ 37 and $38+$ years old. The findings from this study suggested there was no significant difference level in CTDS scores for the five groups: $\mathrm{F}(4,325)=1.453, \mathrm{p}=.216$ (Table 4$)$.

Table 4. One-way variance analysis of differential between the Total Critical Thinking Disposition in different age categories

\begin{tabular}{lrrrrr}
\hline Source & \multicolumn{1}{c}{ SS } & df & MS & F & Sig \\
\hline Between-group & 89.59 & 4 & 22.397 & 1.453 & .216 \\
Within-group & 5009.02 & 325 & 15.412 & & \\
Total & 5098.61 & 329 & & & \\
\hline
\end{tabular}

Looking more closely into the subscales revealed the same findings. As seen in Table 5, there was no significant difference in Reflective Scepticism subscale scores for the five groups: $F(4,331)=1.940, p=.103$. This finding suggested the Reflective Scepticism of graduate students did not vary significantly according to age.

Table 5. One-way variance analysis of differential between the Reflective Scepticism in different age categories

\begin{tabular}{lrrrrrr}
\hline Source & \multicolumn{1}{c}{ SS } & df & MS & F & Sig \\
\hline Between-group & 22.97 & 4 & 5.743 & 1.940 & .103 \\
Within-group & 979.88 & 331 & 2.960 & & & \\
Total & 1002.85 & 335 & & & & \\
\hline
\end{tabular}

Likewise in Table 6, there was no significant difference at .05 level of significance in Critical Openness subscale scores for the five groups: $F(4,325)=1.208, p=.307$. In other words, Critical Openness of graduate students in this study did not 
vary significantly according to age.

Table 6. One-way variance analysis of differential between the Critical Openness in different age categories

\begin{tabular}{lrrrrr}
\hline Source & \multicolumn{1}{c}{ SS } & df & MS & F & Sig \\
\hline Between-group & 33.34 & 4 & 8.334 & 1.208 & .307 \\
Within-group & 2241.24 & 325 & 6.896 & & \\
Total & 2274.57 & 329 & & & \\
\hline
\end{tabular}

Hence, the researcher concluded that age made no significant contribution to changes in graduate students' critical thinking disposition.

\subsection{Emotional Intelligence and Gender}

This study explored the difference between male and female graduate students in terms of their levels of emotional intelligence. To achieve this, an independent samples t-test was conducted to compare the emotional intelligence scores for men and women. As shown in Table 7, there was no significant difference in scores for male $(\mathrm{M}=126.88, \mathrm{SD}=8.74)$ and female graduate students $(\mathrm{M}=128.68, \mathrm{SD}=9.996 ; \mathrm{t}(323)=-1.42, \mathrm{p}=.157)$. Furthermore, the magnitude of the differences in the means (mean difference $=-1.79,95 \% \mathrm{CI}$ : -4.27 to .69 ) was also very small (eta squared $=.006$ ).

Table 7. T-test result in difference of Emotional Intelligence for male and female graduate students

\begin{tabular}{lllllll}
\hline Sex & $\mathrm{N}$ & Mean & SD & t value & df & Sig \\
\hline Male & 78 & 126.88 & 8.74 & & & \\
& & & & -1.42 & 323 & .157 \\
Female & 247 & 128.68 & 9.996 & & & \\
\hline
\end{tabular}

\subsection{Critical Thinking Disposition and Gender}

Findings of this study suggested there was no significant difference in overall critical thinking disposition scores for men $(M=45.85, S D=4.17)$ and women $(M=45.26, S D=3.85 ; \mathrm{t}(330)=1.180, \mathrm{p}=.239)$ (Table 8). Moreover, the magnitude of the differences in the means (mean difference $=.59,95 \% \mathrm{CI}$ : -.396 to 1.58 ) was very small (eta squared $=$ $.004)$.

Table 8. T-test result for difference of Overall Critical Thinking Disposition for male and female graduate students

\begin{tabular}{lcccccc}
\hline Sex & N & Mean & SD & t value & df & Sig \\
\hline Male & 81 & 45.85 & 4.17 & & & .239 \\
& & & & 1.180 & 330 & \\
\hline
\end{tabular}

Likewise for the subscale of Reflective Scepticism (Table 9), results of this study revealed that there was no significant difference in scores for men $(\mathrm{M}=16.94, \mathrm{SD}=1.72)$ and women $(\mathrm{M}=16.55, \mathrm{SD}=1.72 ; \mathrm{t}(336)=1.816, \mathrm{p}=.070)$. In addition, the magnitude of the differences in the means (mean difference $=.39,95 \% \mathrm{CI}$ : -.033 to .822 ) was very small (eta squared $=.0097)$.

Table 9. T-test result in difference of the Reflective Scepticism for male and female graduate students

\begin{tabular}{lcccccc}
\hline Sex & N & Mean & SD & t value & df & Sig \\
\hline Male & 83 & 16.94 & 1.72 & & & \\
& & & & 336 & 1.816 & .070 \\
Female & 255 & 16.55 & 1.72 & & & \\
\hline
\end{tabular}

Similarly, for the subscale of Critical Openness (Table 10), results of this study revealed that there was no significant difference in scores for men $(\mathrm{M}=28.89, \mathrm{SD}=2.97)$ and women $(\mathrm{M}=28.74, \mathrm{SD}=2.52 ; \mathrm{t}(119.5)=.415, \mathrm{p}=.679)$. The magnitude of the differences in the means (mean difference $=.15,95 \% \mathrm{CI}$ : -.573 to .876 ) was also very small (eta squared $=.0005)$. 
Table 10. T-test result in difference of the Critical Openness for male and female graduate students

\begin{tabular}{lcccccc} 
Sex & N & Mean & SD & t value & df & Sig \\
\hline Male & 81 & 28.89 & 2.97 & & & \\
& & & & .415 & 119.5 & .679 \\
Female & 251 & 28.74 & 2.52 & & & \\
\hline
\end{tabular}

There was no significant difference in critical thinking disposition of men and women in this study. Therefore, the findings suggested that critical thinking disposition does not vary significantly according to gender.

\subsection{Emotional Intelligence and Courses of Study}

The researcher conducted a one-way between-groups analysis of variance to investigate the impact of academic specialization on levels of emotional intelligence, as measured by the EIS. The findings of this study suggested there was no significant difference at .05 level of significance in EIS scores for the four groups of respondents enrolled in UPM: $F(3,321)=.666, p=.573$ (Table 11). This meant the emotional intelligence of graduate students from degrees of Master of Education (M.Ed.), Master of Science (M.S.), Master of Human Resource Development (M.HRD) and Doctor of Philosophy $(\mathrm{PhD})$ was not significantly different.

Table 11. One-way variance analysis of differential between the Emotional Intelligence in different courses of study

\begin{tabular}{lrrrrr}
\hline Source & \multicolumn{1}{c}{ SS } & df & MS & F & Sig \\
\hline Between-group & 189.64 & 3 & 63.214 & .666 & .573 \\
Within-group & 30466.66 & 321 & 94.912 & & \\
Total & 30656.30 & 324 & & & \\
\hline
\end{tabular}

\subsection{Critical Thinking Disposition and Courses of Study}

A one-way between-groups analysis of variance was conducted to explore the impact of academic specialization on levels of critical thinking disposition, as measured by the CTDS. Respondents were divided into four groups according to the types of degree they were enrolled in at UPM. They were M.Ed., M.S., M.HRD and PhD In the current study, as shown in Table 12, there was no significant difference in overall critical thinking disposition scores for the four groups: $\mathrm{F}(3,328)=.966, \mathrm{p}=.409$.

Table 12. One-way variance analysis of differential between the Overall Critical Thinking Disposition in different courses of study

\begin{tabular}{lrrrrr}
\hline Source & \multicolumn{1}{c}{ SS } & df & MS & F & Sig \\
\hline Between-group & 44.86 & 3 & 14.952 & .966 & .409 \\
Within-group & 5079.06 & 328 & 15.485 & & \\
Total & 5123.92 & 331 & & & \\
\hline
\end{tabular}

For the subscale of Reflective Scepticism (Table 13), findings of this study suggested there was no significant difference in scores for the four groups: $\mathrm{F}(3,334)=1.599, \mathrm{p}=.189$. Therefore, the Reflective Scepticism of graduate students in this study did not vary significantly according to course of study.

Table 13. One-way variance analysis of differential between the Reflective Scepticism in different courses of study

\begin{tabular}{lrrrrr}
\hline Source & \multicolumn{1}{c}{ SS } & \multicolumn{1}{c}{ df } & MS & F & Sig \\
\hline Between-group & 14.21 & 3 & 4.738 & 1.599 & .189 \\
Within-group & 989.47 & 334 & 2.962 & & \\
Total & 1003.68 & 337 & & & \\
\hline
\end{tabular}

Similarly, for the subscale of Critical Openness (Table 14), there was no significant difference in scores for the four groups: $\mathrm{F}(3,328)=.535, \mathrm{p}=.658$. This result revealed that the Critical Openness of graduate students in this study did not vary significantly according to the course of study. 


\begin{tabular}{lrrrrl}
\hline \multicolumn{6}{l}{ Table 14. One-way variance analysis of differential between the Critical Openness in different courses of study } \\
\hline Source & \multicolumn{1}{c}{ SS } & \multicolumn{1}{c}{ df } & \multicolumn{1}{c}{ MS } & \multicolumn{1}{l}{ F } & Sig \\
\hline Between-group & 11.17 & 3 & 3.723 & .535 & .658 \\
Within-group & 2280.89 & 328 & 6.954 & & \\
Total & 2292.06 & 331 & & & \\
\hline
\end{tabular}

Accordingly, this meant that the critical thinking disposition of graduate students from different degree courses was not significantly different.

\section{Discussion}

\subsection{Emotional Intelligence}

The results of this study have revealed a mean score of 128.25 against a full score of 165 . As higher scores indicate greater emotional intelligence (Schutte et al., 2002), the graduate students in this study can be regarded as emotionally intelligent. This meant that they have the ability to perceive, understand, regulate, and harness emotion adaptively. In other words, they could recognize, manage, and understand the emotion in others, and to utilize this information to guide their thoughts and actions (Mayer \& Salovey, 1997). Therefore, they could effectively apply sound judgment and reasoning to situations and circumstances in the process of shaping an emotional response to specific situations (Elder, 1997).

Sharing the same findings on graduate students with high emotional intelligence is a study in India by Bhaskar, Aruna, Rajesh, Suganna, and Suvarna (2013) using the Goleman's model (1998) on postgraduate students of Padodontics and Preventive Dentistry. They found that $19 \%$ and $58 \%$ of the 240 respondents had very high and high EI scores, respectively. In fact, none of the students had poor or very poor scores. However, a study by Faye, Kalra, Swamy, Shukla, Subramanyam, and Kamath (2011) on medical postgraduates from tertiary care hospital in Mumbai has revealed that more than $70 \%$ of the respondents had poor emotional intelligence according to the Emotional Quotient Self-Assessment checklist. These contradictory findings are indicative of differences in emotional intelligence among graduate students. Thus, not all highly educated people have high emotional intelligence.

\subsection{Critical Thinking Disposition}

The findings also indicate that the graduate students in this study have high overall critical thinking disposition, a mean score of 45.40 against the range of $45-55$ for high disposition. And, they were moderate on the subscale of Reflective Scepticism (mean score of 16.64 against 13-16 for moderate disposition) and Critical Openness (mean score of 28.77 against 22-28 for moderate disposition) (Sosu, 2013). Hence, it was still reasonable to conclude that they have the tendency to learn from their past experiences and be questioning of evidence. Likewise, they would tend to be actively open to new ideas, critical in evaluating these ideas and modifying their thinking in light of convincing evidence (Sosu, 2013).

Past studies, however, have revealed inconsistent findings. Murray (2003) who examined critical thinking among graduate level students has found that the master's level counseling students and master's level business students show a positive disposition toward critical thinking. Nevertheless, scores on one of the sub-scales, Truth-seeking, was below what the authors of the instrument would deem as a positive inclination. Other studies involving undergraduate students have found that those in the College of Humanities achieved optimal level of critical thinking disposition (Khandaghi, Pakmehr, \& Amiri, 2011) while prospective science teachers have medium and low levels of critical thinking disposition (Demirhan \& Köklükaya, (2014). Hence, the need for more studies in critical thinking disposition arises especially as some researchers argue that before critical thinking skills can be examined, a positive disposition to think critically must exist (Facione, Sanchez, \& Facione, 1994; Thayer-Bacon, 1993).

\subsection{Emotional Intelligence and Critical Thinking Disposition}

Overall, the result of this study suggests that there was significantly a strong, positive correlation between the graduate students' emotional intelligence and their critical thinking disposition $(\mathrm{r}=.609, \mathrm{n}=319, \mathrm{p}<.05)$. However, it was not possible to ascertain whether higher emotional intelligence has led to greater critical thinking disposition or greater critical thinking disposition has resulted in higher emotional intelligence among participants of this study. Alternatively, a third variable might have influenced the associations.

Stedman and Andenoro (2007) found a substantially positive relationship between emotional intelligence and critical thinking disposition in undergraduate leadership students. Similarly, high school English language teachers and Iranian EFL learners revealed there was a significant positive relationship between their critical thinking and emotional intelligence (Ebrahimi \& Moafian, 2012; Afshar \& Rahimi, 2014). Contrary, study by Murensky (2000) on managers in high-level leadership positions revealed a significant, negative correlation between critical thinking ability and emotional intelligence. Although moderate in size, it can be inferred that those individuals who are higher in critical thinking are less engaged in building and maintaining relationships while those with lower scores might be more inclined to pursue social meanings. This inconsistency substantiates Elder's (1996) contention regarding the fluid 
association between thought and feelings. Elder argued that the human mind is composed of at least three main functions, namely, cognition, feelings, and volition. While processing is in progress, these three functions, though theoretically distinctive, have a dynamic and intimate relation to each other.

\subsection{Emotional Intelligence and Age}

This study has revealed that there was no significant difference in emotional intelligence for the five different age groups: $\mathrm{F}(4,318)=1.754, \mathrm{p}=.138$. The categories were $\leqslant 25,26-28,29-32,33-37$ and 38+ years old. Thus, regardless of the age, the difference in graduate students' emotional intelligence has remained non-significant. Hence, the hypothesis which stated that age made no significant contribution to changes in graduate students' emotional intelligence was accepted.

This finding was supported by Gibson (2004) who conducted a study on graduate students (master's level), Topaloğlu (2014) on vocational college students and Doherty, Cronin, and Offiah (2013) on graduate medical students with no observed relationship between age and emotional intelligence. However, a study by McKinley, Petrusa, Fiedeldey-Van Dijk, Mullen, Smink, Scott-Vernaglia, Kent, Black-Schaffer, and Phitayakorn (2014) have shown that age was a small but significant demographic predictor of global emotional intelligence of resident physicians across multiple specialties. Therefore, one's emotional intelligence might not necessarily increase with age but might increase with greater experiential learning opportunities.

\subsection{Critical Thinking Disposition and Age}

Likewise, findings from this study show that there were no significant differences in the overall critical thinking disposition $[\mathrm{F}(4,325)=1.453, \mathrm{p}=.216]$ as well as in the subscales of Reflective Scepticism $[\mathrm{F}(4,331)=1.940, \mathrm{p}=.103]$ and Critical Openness $[\mathrm{F}(4,325)=1.208 \mathrm{p}=.307]$ for the five different age groups. The researcher hence concluded that the critical thinking disposition of graduate students in this study did not vary significantly according to their age. Accordingly, the hypothesis which stated that age made no significant contribution to changes in graduate students' critical thinking disposition was accepted.

Naber \& Wyatt (2014) who investigated the critical thinking skills and dispositions of baccalaureate nursing students shared the same findings. Nevertheless, a study by Emir (2009) on the Education Faculty students' critical thinking disposition revealed otherwise with significant difference favoring older age groups. This might result from the fact that as the age increases, the confidence of the individual in his/her mental processes and his disposition to acquire and learn new things increase. This is in accordance with Facione and Facione (1997) who theorized that as an individual gets older, they will have higher critical thinking disposition scores than a younger person (as cited in Wangensteen, Johansson, Björkström \& Nordström, 2010).

\subsection{Emotional Intelligence and Gender}

Based on the findings of this study, the result showed that there was no significant difference between the Emotional Intelligence mean scores of male $(\mathrm{M}=126.88, \mathrm{SD}=8.74)$ and female graduate students $(\mathrm{M}=128.68, \mathrm{SD}=9.996 ; \mathrm{t}(323)=$ $-1.42, \mathrm{p}=.157)$. In other words, the men and women in this study did not differ significantly in terms of their emotional intelligence. Hence, the hypothesis which stated that gender made no significant contribution to changes in graduate students' emotional intelligence was accepted.

Agreeing to this finding is the study by Birks, McKendree, and Watt (2009) on undergraduate dental, nursing and medical students, and postgraduate mental health workers which found no significant differences in emotional intelligence between males and females. This finding however contradicts with previous research by Jayawardena (2012) on master's in management students where the female students exhibited slightly superior levels of emotional intelligence. Likewise, other studies by Gibson (2004) and Doherty et al. (2013) found female graduate students scored higher than their male counterparts in emotional intelligence. Nevertheless, despite both having high emotional intelligence scores, Bhaskar et al. (2013) have suggested the male postgraduate students in India had higher scores for dimensions of self-awareness, social awareness and social skills than their female counterparts. This could be due to other influencing factors as a study by Faye, et al. (2011) on emotional intelligence of medical postgraduates in Mumbai found that married males were more confident and empathizing.

\subsection{Critical Thinking Disposition and Gender}

This study reveals that there is no significant difference between the male $(\mathrm{M}=45.85, \mathrm{SD}=4.17)$ and female graduate students $(\mathrm{M}=45.26, \mathrm{SD}=3.85 ; \mathrm{t}(330)=1.180, \mathrm{p}=.239)$ in terms of their critical thinking disposition. Similarly, regardless of the gender, the difference in graduate students' Reflective Scepticism and Critical Openness (the two subscales of CTDS) has remained non-significant. Their respective results are men $(\mathrm{M}=16.94 \mathrm{SD}=1.72)$ and women $(\mathrm{M}=16.55, \mathrm{SD}=1.72 ; \mathrm{t}(336)=1.816, \mathrm{p}=.070)$ for Reflective Scepticism and men $(\mathrm{M}=28.89, \mathrm{SD}=2.97)$ and women $(\mathrm{M}=28.74, \mathrm{SD}=2.52 ; \mathrm{t}(119.5)=.415, \mathrm{p}=.679)$ for Critical Openness. In other words, the women and men in this study do not vary significantly in terms of their disposition toward critical thinking. Therefore, the hypothesis which stated that gender made no significant contribution to changes in graduate students' critical thinking disposition was accepted.

Agreeing with this, critical thinking disposition did not significantly vary according to gender for language and Mathematics education students (Turan, Kolayis, Ulusoy, 2012) as well as for humanities fields undergraduates (Khandaghi, et al., 2011). Likewise for the master's level counseling students and master's level business students. Men 
however scored higher than women on the Analyticity sub-scale of the CCTDI (Murray, 2003). Some cultures that discourage the enquiry and curiosity in females inhibit the critical thinking disposition and further enhance the gender differences in critical thinking (Khandaghi \& Pakmeh, 2012). Hence, gender, as a predictor of critical thinking disposition is still a variable that should be included in the explanation of critical thinking and warrant further study.

\subsection{Emotional Intelligence and Courses of Study}

The graduate students in this study were from degrees leading to Master of Education, Master of Science, Master of Human Resource Development and Doctor of Philosophy. Findings of this study have shown that there was no significant difference in emotional intelligence scores for the four groups: $F(3,321)=.666, p=.573$. This meant that the emotional intelligence of graduate students from different courses of study was not significantly different. The null hypothesis which stated that course of study made no significant impact in graduate students' emotional intelligence was therefore accepted.

Similarly, Birks et al. (2009) found students in different health profession courses did not show significant differences in emotional intelligence. Their study involved groups of undergraduate dental, nursing and medical students, and postgraduate mental health workers. Another study on vocational college students by Topaloğlu (2014) also revealed no meaningful difference between the emotional intelligence scores and the departments they were studying at. The five different academic departments were Child Development, Laboratory and Veterinary Medicine, Tourism and Hospitality Management, Automotive Technologies, and Natural Gas and Sanitary Systems. One explanation that may account for these results is that emotional intelligence has nothing to do with the courses of study. It is probably about accumulation of life experiences that where people get wiser (emotionally intelligent) as they get older.

\subsection{Critical Thinking Disposition and Courses of Study}

Simultaneously, this study demonstrated there was no significant difference in overall critical thinking disposition scores for the four different courses of study: $\mathrm{F}(3,328)=.966, \mathrm{p}=.409$. Subscales Reflective Scepticism and Critical Openness have also shown the same non-significant findings. The results were $F(3,334)=1.599, p=.189$ for Reflective Scepticism and $\mathrm{F}(3,328)=.535, \mathrm{p}=.658$ for Critical Openness. This indicated that graduate students in this study leading to M.Ed., M.S., M.HRD and PhD did not differ significantly in their disposition toward critical thinking. Thus, the hypothesis which stated that course of study made no significant impact in graduate students' critical thinking disposition was accepted.

Murray's study (2003) also did not support the hypothesis that master's level counseling students would score higher than master's level business students. Likewise, no significant difference was found between the critical thinking dispositions of prospective teachers in different scientific fields of study (biology, physics, chemistry and mathematics). This result was attributed to the common characteristics of the basic sciences which share similar methodologies (Kezer \& Turker, 2012). However, Mathematics education students' critical thinking disposition was found to be higher than Turkish language education students (Turan et al., 2012). One explanation for this inconsistency is that possibly certain courses of study do engage their students in deep learning which requires more critical thinking. Additional evidence however awaits further research.

\section{Conclusion}

This study was one of the very few studies that examined the relationship of emotional intelligence and critical thinking disposition in the context of graduate students. The graduate students in this study have reasonable level of emotional intelligence and critical thinking disposition. There was a significantly strong positive correlation between the graduate students' emotional intelligence and their critical thinking disposition. Exploratory in nature, this study did not intend to provide definitive evidence of the links between emotional intelligence and critical thinking disposition. This study also found no significant differences in terms of age, gender, and course of study in relation to these two variables.

Readers should approach this study with caution since its generalizability would be limited to graduate students in public universities studying in the field of education. The emotional intelligence and critical thinking disposition instruments used in this study were abbreviated in nature. Moreover, the two variables under study were measured as subjects' perceptions, not actual behaviors.

Recognizing the significant correlation between emotional intelligence and critical thinking disposition, educators should seize the opportunity to work on either one construct while reaping the benefits of the correlating construct. For example, a teacher may teach his or her students to be emotionally intelligent and at the same time indirectly promoting the students' critical thinking disposition. Teachers, however, first of all, must teach with emotional intelligence. This includes: creating a positive emotional climate; recognizing and working with the feelings of teachers themselves and of the students; using listening skills with groups as well as with individuals; dealing with students' expectations; and having a developed self-awareness (Mortiboys, 2012). Alternatively, for instance, educators may emulate the learning model using business simulation to encourage critical thinking disposition (Bell \& Loon, 2015) and indirectly developing the emotional intelligence of students provided that the content of the simulation is suitable for the student cohort in terms of experience, knowledge, and complexity (Moizer, Lean, Towler, et al., 2009; Sutcliffe, 2002). Let students get into the habit of using them whenever it is appropriate, do not just acquire the skills, but value them - and use them; in short, become a critical thinker and emotionally intelligent person. 
Future research in emotional intelligence and critical thinking could consider the developmental, neuropsychological, and information processing approach. Imminent work would also benefit from other audiences, different research methodology, and more comprehensive instruments. These recommendations hopefully might help to enrich our understanding of these two important constructs and thus enhance the existing research literature.

\section{Acknowledgements}

The author wishes to thank Assoc. Prof. Dr. Aminuddin Hassan from Universiti Putra Malaysia, Serdang, Malaysia who has rendered great help in the completion of this project. Highest gratitude also goes to Dr Edward Sosu from University of Strathclyde, Glasgow, United Kingdom as well as Dr. Nicola Schutte from University of New England, Armidale, NSW, Australia and her colleagues who gave permission to use the measurement tools in this study.

\section{References}

Afshar, H. S., \& Rahimi, M. (2014). The relationship among critical thinking, emotional intelligence, and speaking abilities of Iranian EFL learners. Procedia - Social and Behavioral Sciences, 136, 75 - 79.

Bensley, D. A. (2006). Why great thinkers sometimes fail to think critically. Skeptical Inquirer, 30, 47-52.

Bhaskar, D. J., Aruna, D. S., Rajesh, G., Suganna, M., \& Suvarna, M. (2013). Emotional intelligence of padodontics and preventive dentistry postgraduate students in India. European Journal of Dental Education, 17(1), e5-e9. doi:http://dx.doi.org/10.1111/j.1600-0579.2012.00750.x

Birks, Y., McKendree, J., \& Watt, I. (2009). Emotional intelligence and perceived stress in healthcare students: A multiinstitutional, multi-professional survey. BMC Medical Education, 9, 61. doi:http://dx.doi.org/10.1186/1472-6920-9-61

Blom Kemdal, A., \& Montgomery, H. (1997). 'Perspectives and emotions in personal decision-making', in R. Raynard, R. Ctozier \& O. Svenson, Decision-making (pp. 72-89), London: Routledge.

Brackett, M. A., \& Mayer, J. D. (2003). Convergent, discriminant and incremental validity of competing measures of emotional intelligence. Personality and Social Psychology Bulletin, 29, 1147-1158.

Brookfield, S. (1987). Developing Critical Thinking, Milton Keynes, SRHE and Open University Press.

Cohen, J. W. (1998). Statistical power analysis for the behavioral sciences (2nd ed.). Hillsdale, NJ: Lawrence Erlbaum Associates.

Damasio, A. (2000). The Feeling of What Happens - Body, Emotion and Making of Consciousness. London, Virago.

Demirhan, E., \& Köklükaya, A. N. (2014). The Critical Thinking Dispositions of Prospective Science Teachers. Procedia - Social and Behavioral Sciences, 116, 1551-1555.

DeVellis, R.F. (2003). Scale development: Theory and applications (2nd ed.). Thousand Oaks, California: Sage.

Dewey, J. (1933). How We Think: A restatement of the relation of reflective thinking to the educative process. Boston: D.C. Health and Company.

Doherty, E. M., Cronin, P. A., \& Offiah, G. (2013). Emotional intelligence assessment in a graduate entry medical school curriculum. BMC Medical Education, 13, 38. doi:http://dx.doi.org/10.1186/1472-6920-13-38

Ebrahimi, M. R., \& Moafian, F. (2012). Does emotional intelligence or self-efficacy have something to do with high school English teachers' critical thinking, considering demographic information? International Journal of Linguistics, 4(4), 224-242. Retrieved from http://search.proquest.com/docview/1323942080?accountid=27932

Edith, Claros., \& Manoj, Sharma. (2012). The relationship between emotional intelligence and abuse of alcohol, marijuana, and tobacco among college students. Journal of Alcohol \& Drug Education, 56(1), 8-37.

Elder, L. (1996). Cognition and affect: critical thinking and emotional intelligence. Inquiry: critical thinking across the disciplines, XVI (2).

Elder, L. (1997). Critical thinking: The key to emotional intelligence. Journal of Developmental Education, 21(1), 4044.

Emir, Serap. (2009). Education faculty students' critical thinking disposition according to academic achievement. Procedia - Social and Behavioral Sciences, 1(1), 2466-2469.

Ennis, R.H. (1987). A taxonomy of critical thinking dispositions and abilities. In J.B. Baron \& R.J. Sternberg (Eds.) Teaching thinking skills: Theory and practice (pp. 9-26). New York: Freeman.

Facione, P., Facione, N., \& Giancarlo, C. (2001). California Critical Thinking Disposition Inventory - Inventory manual. Millbrae, CA: The California Academic Press.

Facione, P. A. (1990). Critical thinking: A statement of expert consensus for purposes of educational assessment and instruction. Millbrae, CA: California Academic Press.

Facione. P. A., \& Facione, N. C. (1992). The California Critical Thinking Dispositions Inventory (CCTDI) and the 
CCTDI Test Manual. Millbrae, CA: California Academic Press.

Facione, P. A., Sanchez, C. A., \& Facione, N. C. (1994). Are college students disposed to think? Milbrae, CA: The California Academic Press.

Faye, A., Kalra, G., Swamy, R., Shukla, A., Subramanyam, A., \& Kamath, R. (2011). Study of emotional intelligence and empathy in medical postgraduates. Indian Journal of Psychiatry, 53(2), 140-144. doi:http://dx.doi.org/10.4103/0019-5545.82541

Fitness, J. (2001). Emotional intelligence and intimate relationships. In J. Ciarrochi, J. P. Forgas, \& J. D. Mayer (Eds.), Emotional intelligence in everyday life (pp. 98-112). New York: Psychology Press.

Fitness, J. (2006). The emotionally intelligent marriage. In J. Ciarrochi, J. P. Forgas, \& J. D. Mayer (Eds.), Emotional intelligence in everyday life (2nd ed., pp. 129-139). New York: Psychology Press.

Flavell, J.H. (1979). Metacognition and cognitive monitoring: A new area of cognitive-development inquiry. American Psychologist, 34, 906-911.

Gardner, K.J., \& Qualter, P. (2010). Concurrent and incremental validity of three trait emotional intelligence measures. Australian Journal of Psychology, 62(1), 5-13.

Gibson, G. J. (2004). Emotional intelligence and performance in a graduate school counseling program. (Order No. 3162899, The University of North Dakota). ProQuest Dissertations and Theses, 113-113 p. Retrieved from http://search.proquest.com/docview/305166939?accountid=27932. (305166939).

Goleman, D. (1995). Emotional Intelligence: Why It Can Matter More than IQ. New York: Bantam Books.

Goleman, D. (1998). Working with emotional intelligence. New York: Bantam Books.

Halpern, D. F. (2003). Thought and knowledge: An introduction to critical thinking (4th ed.). Mahwah, NJ: Lawrence Erlbaum Associates, Inc.

Jayawardena, L. N. A. C. (2012). Transformational leadership and emotional intelligence of graduate managers. Management and Production Engineering Review, 3(3), 28. doi:http://dx.doi.org/10.2478/v10270-012-0021-1

Kezer \& Turker (2012). Comparison of the critical thinking dispositions of (studying in the secondary science and mathematics division) preservice teachers. Procedia - Social and Behavioral Sciences 46, 1279-1283.

Khandaghi, M. A., \& Pakmeh, H. (2012). Critical thinking disposition: A neglected loop of humanities curriculum in higher education. Cypriot Journal of Educational Sciences, 7(1), 01-13. Retrieved from http://world-educationcenter.org/index.php/cjes/article/viewFile/249/7.1

Khandaghi, M. A., Pakmehr, H., \& Amiri, E. (2011). The status of college students' critical thinking disposition in humanities. Procedia Social and Behavioral Sciences, 15, 1866-1869.

Mayer, J. D., \& Salovey, P. (1997). What is emotional intelligence? In P. Salovey, \& D. Sluyter, Emotional development and emotional intelligence: educational implications. New York: Basic Books.

Matthews, G., Zeidner, M., \& Roberts R.D. (2002). Emotional intelligence: Science and myth. Cambridge, MA: MIT Press.

McKinley, S. K., Petrusa, E. R., Fiedeldey-Van Dijk, C., Mullen, J. T., Smink, D. S., Scott-Vernaglia, S. E., Kent, T. S., Black-Schaffer, W. S., \& Phitayakorn, R.(2014). A multi-institutional study of the emotional intelligence of resident physicians. The American Journal of Surgery. http://dx.doi.org/10.1016/j.amjsurg.2014.09.015.

Ministry of Education Malaysia. (2013). Malaysia Education Blueprint 2013-2025. Putrajaya: Author.

Moizer, J., Lean, J., Towler, M., et al. (2009). Simulations and games overcoming the barriers to their use in higher education. Active Learning in Higher Education, 10(3), 207-224.

Moon, Jennifer. (2008). Critical Thinking: An exploration of theory and practice. New York: Routledge.

Mortiboys, A. (2012). Teaching with emotional intelligence: A step by step guide for higher and further education professionals (2nd ed.). New York, NY: Routledge.

Murensky, C. L. (2000). The relationships between emotional intelligence, personality, critical thinking ability and organizational leadership performance at upper levels of management. (Order No. 9962991, George Mason University). ProQuest Dissertations and Theses, 152-152 p. Retrieved from http://search.proquest.com/docview/304670322? accountid=27932. (304670322).

Murray, P. E. (2003). A comparative study to assess the critical thinking dispositions between master's level counseling students and master's level business students. (Order No. 3098697, University of South Carolina). ProQuest Dissertations and Theses, 101-101 p. Retrieved from http://search.proquest.com/docview/305315455?accountid=27932. (305315455).

Naber, J., \& Wyatt, T. H. (2014). The effect of reflective writing interventions on the critical thinking skills and dispositions of baccalaureate nursing students. Nurse Education Today, 34, 67-72.

Nelson-Jones, R. (1994). Thinking Skills. London: Cassell. 
Pallant, J. (2010). SPSS survival manual (4th ed.). Berkshire: Maidenhead. McGraw-Hill.

Rippen, A., Booth, C., Bowie, S., \& Jordan, J. (2002). A complex case: Using the case study method to explore uncertainty and ambiguity in undergraduate business education. Teaching in Higher Education, 7(4), 429.

Ritchhart, R. (1997). Of dispositions, attitudes, and habits: Exploring how emotions shape our thinking. Harvard Project Zero. Cambridge: $\quad$ Mass. $\quad$ Retrieved from http://s3.amazonaws.com/academia.edu.documents/30332295/article1.pdf?AWSAccessKeyId=AKIAJ56TQJRTWSMT NPEA\&Expires $=1443700435 \&$ Signature $=$ fxZBFe8cBN\%2BmECH5fvqRipdLqEs\%3D\&response-contentdisposition=inline

Schutte, N.S., Malouff, J.M., Hall, L.E., Haggerty, D.J., Cooper, J.T., Golden, C.J., \& Dornheim, L. (1998). Development and validation of a measure of emotional intelligence. Personality and Individual Differences, 25, 167177.

Schutte, N., Malouff, J., Simunek, M., McKenley, J., \& Hollander, S, (2002). Characteristic emotional intelligence and emotional well-being. Cognition and Emotion, 16(6), 769-785.

Sosu, Edward. M. (2013). The development and psychometric validation of a critical thinking disposition scale. Thinking Skills and Creativity, 9, 107-119.

Stedman, N.L.P. \& Andenoro, A.C. (2007). Identification of relationships between emotional intelligence and critical thinking disposition in undergraduate leadership students. Journal of Leadership Education, 6(2), 190-208.

Sutcliffe, M. (2002). Games, simulations and role playing: The handbook for economic lecturers. Bristol, UK: Economics LTSN. Retrieved from https://www.economicsnetwork.ac.uk/handbook/printable/games_v5.pdf

Tan, Jo-Ann. (July 14-20, 2014). Helping to defuse the graduate employability time bomb. The Edge Malaysia, 1023, \#4-11.

Tempelaar, D.T. (2006). The role of metacognition in business education. Industry and Higher Education, 20(5), 291297.

Thayer-Bacon, B. (1993). Caring and its relationship to critical thinking. Educational Theory, 43(3), 323-341.

Topaloğlu, A. Ö. (2014). The study of college students' emotional intelligence qualities. Procedia - Social and Behavioral Sciences 152, 1274-1281.

Turan, Hakan., Kolayis, Hakan., Ulusoy, Yildiz Oztan. (2012). Comparison of the faculty of education students' critical thinking disposition. Procedia - Social and Behavioral Sciences, 46, 2020-2024.

Wangensteen S., Johansson I.S., Björkström M. E. \& Nordström G. (2010). Critical thinking dispositions among newly graduated nurses. Journal of Advanced Nursing, 66(10), 2170-2181. 